\title{
THE INTERNET AND POLITICS: TRANSFORMATION OF POLITICAL COMMUNICATION
}

\author{
Asuman Kutlu \\ Beykent University
}

\begin{abstract}
Perceived as a professional process in modern democracies, political communication is the interdisciplinary study of the interrelationships between the political system, the media system and citizenship and mainly concerned with how information spreads through media influences politics. The emergence of fast evolving digital technologies has changed the way in which political communication takes considering a wide range of new opportunities and strategies allowing political actors and citizens to rebuild the process. The internet has removed the limitations of conventional media through providing an interactive platform for discussion and debate and changing the relationship between information producers and consumers. Political parties and actors can directly address their voters through their websites and use online communication platforms in election campaigns for their political goals. On the other hand, traditional political acts such as demonstration marches and rallies can be organized through online facilities offered by the Internet. This study focuses on mediated political communication and the changes related to the inclusion of information and communication technologies in politics and the use of digital technologies by political actors in Turkey to achieve their political purposes.
\end{abstract}

Key words: Political communication, Turkey, new communication technologies, politics, elections.

\section{Introduction}

The media acts as bridge between political actors and public and the 2008 Obama Presidential campaign is considered to revolutionize politics and political process. When he announced his candidacy in 2007, Twitter had just started and Obama was the first American

president who understood the power and the political relevance of social media just as John F. Kennedy to understand the power of television. Since he reached millions of followers and donors due to his effective use 
of social media as a major campaign strategy, many political actors acted to adopt new communication technologies, which have a developing role in political communication process in Turkey in the 2000s, about ten years later than Western nations. The term "network citizenship" evolving out of the digital technologies refers to understanding of citizenship, which is more participatory and dependent on rights and freedom than passive and obedient citizens of the past. Especially during the later stages of the Internet development called the Web 2.0 era, digital media have created a new political dialogue. It has taken the power of political messaging away from the mass media model and placed it into peer-to-peer, public discourse. With the internet revolution, politics has been understood in a radically different manner however a conventional distinction can still be drawn concerning interpersonal communications (such as one-to-one discussions, say on door-steps), within group networks (like local meetings) and mass communications through the conventional media (such as newspapers, radio and television broadcasts) (Norris, 2010). The internet have also enabled political actors with limited resources to reach wider audiences and it has allowed political parties in countries having a broad geographical structure such as Turkey to standardize corporate identity. Although the pioneering studies in political communication in Turkey date back to 1960s, they could not go beyond propaganda. The spread of private broadcasting, the spread of public opinion research companies and development of political advertising in 1990s have increased the significance of research in political communication. However, political communication is still perceived as a series of communication activities during the election periods in Turkey rather than a set of activities that require continuity. The first and second sections of the paper presents a review of existing literature on political communication and its transformation through examing the features of by comparing the past and present of political communication. Following these, the third section focuses on the adoption of new communication technologies by political actors both in the eras of Web 1.0. and Web 2.0. in Turkey and the conclusion sums up the discussions.

\section{The Concept of Political Communication}

Since communication is central to any political system, political actors have always had a requirement to communicate with other groups in society and had to convince people to support them for power and position. Traditional definitions of political communication focus on the source and motivation and define it as a series of edicts to society from the ruling group. However considering the role of the media in modern states, political communication depends on three actors which are political sphere, nonstate actors and media outlets which communicates independently but synergistically with one another but much of history, political communication has been a linear, top-down process from leaders to people (Lilleker, 2006:1-5). The research conducted usually describe three distinct ages shaping political communication in many democracies over the postwar period. In the first age, much political communication served to relatively strong and stable political institutions and beliefs. In the second, political parties faced with a more mobile electorate so adapted their 
communications to the news values and formats of limited-channel television and become more professionalized. In the third and still emerging age of media abundance, political communication may be reshaped by five trends, which are intensified professionalizing imperatives, increased competitive pressures, anti-elitist populism, a process of centrifugal diversification, and changes in how people receive politics (Blumler and Kavanagh, 1999). Although the roots of political communication date back to Ancient Greece with the earliest studies of democratic discourse by Aristotle and Plato, the development of political communication can be examined in three main stages.

The earliest classical era of political communications evolved as representative democracies developed during the 18th and 19th centuries. Citizens and politicians were connected directly through election canvassing, town hall meetings, printed handbills and posters, and local rallies and candidate hustings, which were supplemented by the political print media such as newsletters, periodicals, journals, and newspapers. Railways increased the opportunities for party leadership whistle-stop tours and facilitated the cheaper and faster distribution of daily newspapers with commercial advertising reducing the price of masscirculation papers and magazines. Telegraphs connected distant reporters with news-rooms and news wire agencies. The early twentieth century saw the growth of wireless radios, used for leadership fire-side chats and the first party radio political broadcasts. Telephones transformed inter-personal communications and reduced the limits of distance. This era also saw technological advances in photography and wire transmissions, which facilitated publication of realistic visual images, and during the interwar years, film documentaries covered events and breaking developments around the world. The modern era of political communications, following the end of World War II, witnessed the rapidly expanding role of television broadcasting, carrying TV party political broadcasts. Inter-personal communications between party representatives and citizens continued to play a vital role along with mass-circulation of newspapers and magazines, which were later supplemented by expansion of satellite and cable transmissions and channels. The third age of political communications is marked with the rise of the internet and a wide range of digital technologies. Technological advances, leading to the development of the first visual browser in the mid-1990s and the World Wide Web, have transformed political communications beyond all recognition. The developments include a growing expansion of interpersonal and organizational email and text messaging, search engines, the blogosphere, and websites maintained by political actor and social media. Newspapers, radio and television adapting to the digital landscape have taken advantage of new communication technologies (Norris, 2010).

In a democratic state, media are often acclaimed as the fourth additional power controling people in power and report to the electorate. This requires institutional independence from the political system however 
media depend on politics for information. Similarly, political actors depend on media to convey their messages to citizens. The term "political communication" has always been difficult to define since both components of the phrase cover a variety of definitions. Aziz provides one definition of political communication as the use of various communication techniques by political actors to impose their ideological goals and policies to certain groups, masses, or countries and transform them into action when necessary. Considering its historical development, the phenomenon and process of political communication in ancient Greece differs from political communication in the middle Ages, the New Age and today. This difference arises from the fact that societies have dynamic structures, not static (Aziz, 2013:4). However, political communication is not limited to politicians. Anyone, journalists or citizens, who receives, processes, or produces messages directly or indirectly are related to political communication (Graber, 2005: 479). Therefore, we can redefine political communication as a process in which public opinion intervenes in politics and political actors are involved. The mass media create public opinion with the functions of informing, educating, raising awareness and socializing and play an active role in the perception of the system and the transmission of political messages. The mass media set the agenda for the public to determine what to think and talk about and to discuss, and manipulates the society in the political sphere as well as in other social areas. In modern democracies, political communication is mainly carried out through mass media, which transmit political campaigns to electorates. Therefore, political communication strategies have gained a mediated structure in order to reach more voters. Mass media also serve to adopt democratic culture and ideals to the public, to strengthen the belief in democratic institutions and to maintain the political system. When considered in this respect, political communication is examined under three main topics, which are all forms of communication put forward by political actors to achieve their goals, communication directed by electorate to political actors and media-mediated communication involving the actions of political actors.

\section{The Internet and Transformation of Political Communication}

The claims that the internet has "changed everything significantly" are as old as the internet itself but when it comes to politics, we have to acknowledge the internet, unlike any other preceded technology, has revolutionized politics and the political process. Scholars assert many differences between new media and its older counterparts of radio and television but according Rogers, those differences stem from three fundamental distinctions, which are interactivity, de-massification and asynchronicity. The new media are interactive in a way that the one-to-many mass media could not be, it can reach many more individuals. Interactivity is a desired quality of communication systems since such communication is expected to be more accurate, effective and satisfying to the participants who are active in communication process. The new 
communication technologies are de-massified in which a message can be exchanged with each individual in a large audience. The control of mass communication systems have moved from the message producer to the media consumer. The new media are also asynchronous which means that they are capable of sending or receiving a message at a time convenient for the user. The control of time is put in the hands of receivers (Everett, 1986:4-6).

Through reciprocal rather than just one-way communication, citizens are no longer limited to voting, strikes or public gatherings and may become involved in new political activities. People are expected to be more knowledgeable as they can access huge amounts of information and find other people having similar political views to speak, discuss and publish about the political issues. The internet has enabled average citizens to participate in political process. This public space has created a much more democratic and impartial communication platform that brings political actors and citizens together. Comparing the past and present of political communication, we have several main differences. The first of these is the differences in the means of communication. Traditional political communication channels such as newspapers, magazines, television and radio have been replaced by the parties' websites and social media channels such as Facebook, Twitter, YouTube and others. While new media has gained a personalized dimension, the propaganda language dominated by traditional political communication and monologue discourses have been transformed into dialogue as it has taken the power of political messaging away from the mass media model. Social media creates a new political dialogue. The internet have become one of the strongholds of

campaigns during election periods in which politicians could strengthen the ties with their electorate. Their accounts are followed by journalists as well as their supporters and opponents as they are important news sources.

Some political scientists assert that the concepts of direct democracy in which all people can directly participate in the political decision-making process would be realistic thanks to the wide-spread of new communication technologies as they enable people to become an individuals who are well-informed and have the ability to shape the society. It is not possible to reach people individually and ask their ideas with no other technology. However, for other political scientists the internet merely offer new tools that current power elites are using to maintain their dominance (Mosco and Foster, 2001). One can observe the use of the internet in election campaigns for publicity, propaganda and communication with the electorate has played a growing role since the beginning of 2000s. Compared to other mass media, the internet is a technology that spreads very quickly and continuously increases the number of users. The latest data on the internet usage has demonstrated that the number of internet users worldwide has exceeded 4 billion and Turkey has been in 20 top countries with the highest number of internet users (Internet world stats, 2018). The internet began to be 
used in political communication process in Turkey in the 2000s, about ten years later than Western nations. Since 2007, the blocking of social platforms in Turkey has occurred on seven separate occasions due to offensive content to Turkey. For instance in 2007, videos insulting the founder of Turkey, Atatürk, on YouTube caused the platform to be blocked until the videos were removed.

\section{Use of Digital Media in Political Communication}

Turkey is a Republican Parliamentary Democracy and functioned under a multi-party system since 1945 , however in 2018 , Turkey has undergone a change from parliamentary to presidental system in which the office of prime minister was abolished and executive power transferred to the president. Great National Assembly of Turkey has 550 members, representing 81 provinces, elected based on the $10 \%$ election threshold and most mainstream political parties are built on the following principles of Islamism, Nationalism and Kemalism. There are currently five political parties in the parliament. Political parties use election campaigns, a more professional way to make a strong impact on voters and convince them as they mainly aim to win elections, which are the main drivers of democracy, to seize political power. Despite the popularity of social media, politicians and political parties still conduct conventional campaigns and send emails to spread out their message and express themselves better through including images or links showing their practices and promises. 
International Conference on Research in

Humanities and Social Sciences

Serbia | Belgrade | December 15-17, 2018

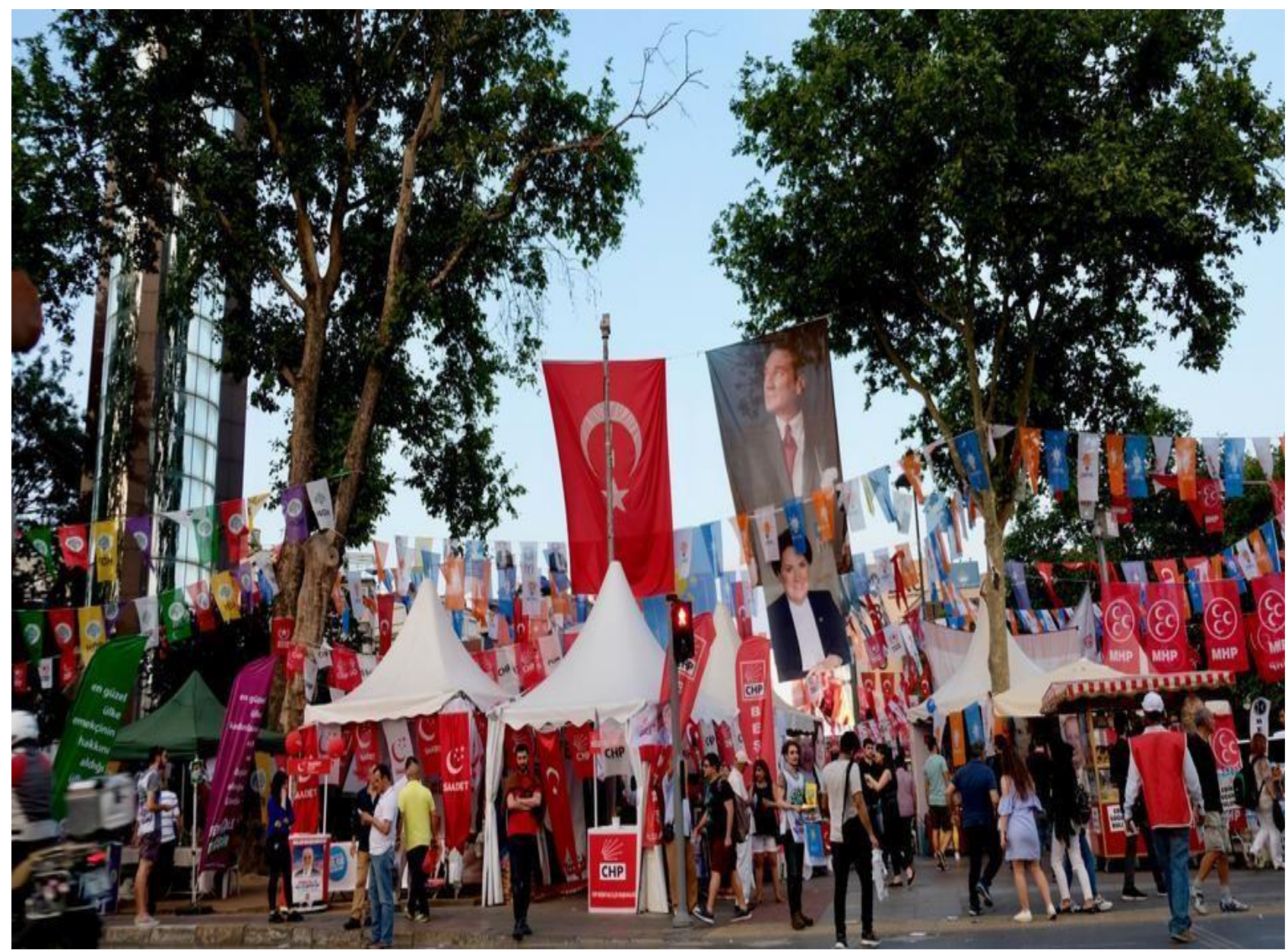

Figure 1: The image above shows one of the busiest districts of Istanbul and flags and tents of five different parties (Turkey elections 2018: Understanding the political parties, 2018).

Besides being cheap, e-mail campaigns allow politicians to personalize their message. In past cycles, they were used as a form of voter contact, however with the implementation of new and creative means of communication, politicians raise money, advertise with less expense, mobilize volunteers and respond to opposition attacks. The 2002 general election was the first election in which parties utilized new communication technologies as a tool for their campaigns. The Young Party, although founded five months before the elections, advertised on popular search engines and sent propaganda e-mails to users. The party received 7.24 percent of the vote however it did not get seats in parliament as it had less than 10 percent of vote share (Genel seçim 2002, 2002). 
Political actors use web pages as an effective tool to publicize their activities, to make electorate engage in communication processes and to develop policies based on feedback. All parties participated in the 2002 election built web sites however they did not include online discussion platforms which bring electrorate and party officials together and the information flow was carried out from top to bottom. Instead of preparing internet-oriented content, materials used in the conventional media were directly transferred to the websites. Therefore the 2007 general election was generally considered the first election in which parties utilized the Internet as an interactive tool for their campaigns. Since RTUK (The Radio and Television Supreme Council) did not allow political commercials shortly before the elections, parties had to run their campaigns on print and online media. Parties uploaded campaign advertisements to YouTube, Turkish newspapers on the internet and news websites and could learn the number of users visiting party websites (Tokgöz, 2008). The statement posted in April, 2007 to the official website of the General Staff to influence the elections, the government decided on early elections making parties to carry out their campaign in a relatively short time. However, parties optimized Web 1.0. Technology in which users could mainly engage with static web sites and passively receive information. Through uploading public statements and announcing political activities and political rallies.

According to a study conducted during presidential elections in 2014, websites of the political parties aimed to inform the public rather than encouraging political participation. According to encoding template used in the research, although all websites investigated were updated daily, they failed in communication network index. Only one of them provided the opportunity for a simultaneous discussion between the candidate and electorate. The candidate whose website had the highest score, received lowest percentage of vote in the election. Considering the election results, the research conluded that the election campaigns carried out through websites did not have a direct impact on the voter preference. Turkey is among the countries with high voter turnout rates however political participation is limited to only electoral process, rather than active participation in decision-making process and public institutions. As a consequence, political actors did not make much of providing two-way communication and take opinions and complaints of the electorate into consideration (Evren, 2015).

The rise of Web 2.0 technologies has further increased the convenience of the internet for political communication. Web 2.0's most important agent is social media and the opportunities offered by social network sites, microblogging and wikis have provided new venues for politics supporting the idea of participatory democracy. The use of social media in diplomatic relations to 


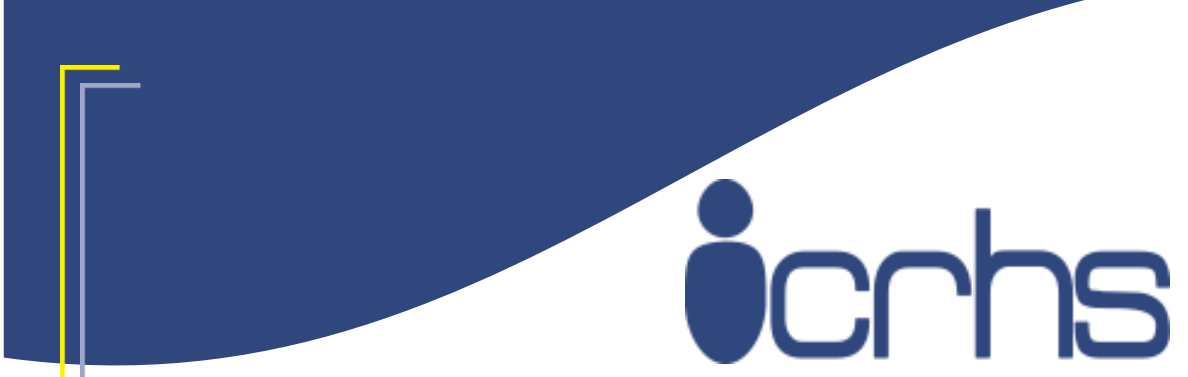

International Conference on Research in Humanities and Social Sciences Serbia | Belgrade | December 15-17, 2018

spread information and engage with the public has created a new name of "Twiplomacy". Politicians can avoid broadcast and print media to reach their potential voters through social media and Turkish politicians have become more during elections to attract young voters as the country has a young and dynamic population. Erdoğan was Turkey's first leader to join social network. According to a report released in 2018, President Recep Tayyip Erdoğan is one of the most active and influential world leaders on social media, especially on Twitter and Periscope. He has 9.7 million likes and more than 112.000 followers, which makes him the most important leader on Periscope and has 12 million followers on Twitter. The Turkish Presidency also activated specific Twitter channels in Arabic, French, German, Russian and Spanish and set up the first channel Twitter account for the hearing impaired which shares videos of the President's speeches with sign language translation. Erdoğan's tweets are relate to government actions as well as local events and meetings.

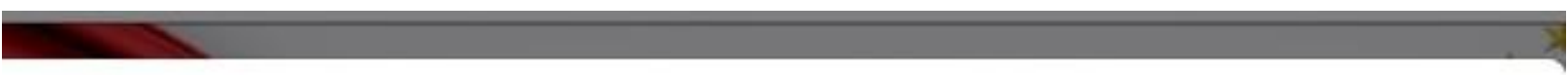

\title{
Çayınız hazırsa geliyorum.
}

\author{
Gamanli @gngratkkk \\ Sayın Cumhurbaşkanım, bir gece de bizim Hüseyin Gazi Yurdunda sizi misafir etsek de \\ sahuru birlikte yapsak? @RT_Erdogan
}

\section{6:26 - 31 May 2018}

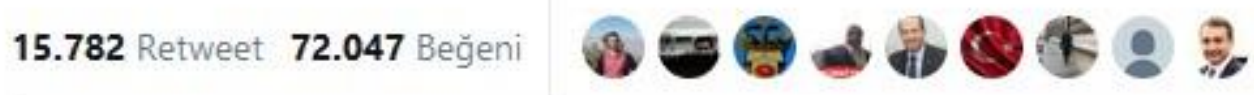 3938 圆 $16 \mathrm{~B} \quad 72 \mathrm{~B}$}

Figure 2: Erdoğan joined youths for a sahur meal at a student dormitory after receiving a sahur invitation from a student via Twitter saying that he is "coming if the tea is ready" (Recep Tayyip Erdoğan @ RT_Erdogan, 2018). 
The leader of the main opposition Republican People's Party, Kemal Kılıçdaroğlu, is approaching 1 million followers. While Erdoğan and Kılıçdaroğlu have Twitter followers measured in millions, neither of the leaders use it interactively. They usually use the platform to post announcements and refrain from answering messages directed by the electorate. 2011 general elections witnessed the effective use of Web 2.0 technologies by political parties and leaders to engage citizens in the election process. Considering the fourth position of Turkey among the top five countries on the Facebook, political parties opened hundreds of Facebook pages and groups. Facebook and Twitter were important venues for political organizations, dissemination of organizational activity and active participation of citizens acting and demanding rather than passive recipients. They served as an alternative public sphere where political leaders could disseminate their political discourses, develop new policies based on feedback from voters and the electorate could express their demands and expectations easily (Aydemir 2008: 57). In 2013, The Justice and Development Party closed many Facebook pages opened under the name of the party and Erdoğan to protect the corporate identity and prevent the abuse of Facebook use by opposing users. Accordingly, in 2015, main opposition Republican People's Party announced that in order to prevent manipulation and disinformation, they suspended Twitter and Facebook accounts bearing the name of the party (CHP Facebook ve Twitter'da, 2018).

Despite the increased popularity of Twitter during Gezi Park protests which took place in 2013, Facebook is the most widely utilized social networking site in Turkey. Political actors' Facebook accounts provide great potential to increase interaction between electotorate and people in power. Users like share or comment on a post and politicians in turn respond to them. Facebook has become the channel of choice for engaging potential voters during election campaigns. While many politicians discover social media channels during election campaigns, social media engagement has become part of normal government communications. As any mistake made on the internet could lead to a political crisis, almost all leaders and parties work with social media teams rather than managing their pages on their own. In 2013, The Justice and Development Party recruited a 6,000-member social-media team charged with sharing news and images on social media that promote the party perspective and monitor online discussions (AK Parti'den, 2018). The use of social media in politics has dramatically changed the way campaigns are run and how political actors interact with potential voters. While Twitter is an ideal platform for politicians to spread both information and opinions, Facebook pages or groups have created an alternative platform for all political institutions to participate in direct dialogues with citizens.

\section{Conclusion}

The internet is changing the way politics work in the world as well as in Turkey and the use of new communication technologies by politicians have recently emerged as the subject of many studies. As many 
politicians have realized the power of online strategies, they have integrated the internet into their campaigns to influence people's attitude, set agendas, and persuade to vote for them. The internet has placed the political messaging into peer-to-peer, public discurse and changed the way how election campaigns were conducted. This study aims to gain insight into how Turkish politicians cultivate new communication technologies to attract voters and emphasizes the overall understanding of the role of them in political communication process. The 2002 general election was the first election in which parties used new communication technologies in election campaigns through advertising and sending propaganda emails to users however, parties utilized the internet as an interactive tool in the general election of 2007 in which users engage with static websites and receive information about political activities and rallies. In 2011, political parties and leaders used Web 2.0 technologies effectively to get in direct touch with especially young voters who are more likely to use technologically advanced products. Considering the position of Turkey among top countries on Facebook and Twitter, politicians prefer social media to convetional platforms to reach their potential voters and many voters follow their behaviors and explanations on social media. It is of great importance that political leaders use their personal pages more interactively rather than using it as an announcement platform as the internet is increasingly used in political context in Turkey.

\section{References}

1. AK Parti'den 6 bin kişilik sosyal medya ordusu. (2018 October, 12). Retrieved from http://www.hurriyet.com.tr/gundem/ak-partiden-6-bin-kisilik-sosyal-medya-ordusu-25115336.

2. Aydemir, T.A.: "Civicweb: Internet, young people and civic participation", Citizenship and cultural identities in the EU: Old questions, new answers, 57-70, Promeda, 2008.

3. Aziz, A.: Siyasal iletişim, Nobel, 2013.

4. Blumler, J.G. and Kavanagh, D.: "The third age of political communication: influences and features", Political Communication, 16 (3), 209-230, 1999.

5. CHP Facebook ve Twitter'da ismini taşıyan hesapları kapattırdı. (2018 September, 30). Retrieved from https://www.haberler.com/chp-nin-basvurusu-uzerine-twitter-ve-facebook-taki-7025452-haberi/. 6.Çayınız hazırsa geliyorum. (2018 September,12). Retrieved from https://twitter.com/RT_Erdogan/status/224724480 .

6. Everett, M.R.: Communication technology: The new media in society, The Free Press, 1986.

7. Evren, F.B.: "Internet usage as a political communication instrument: 2014 presidential election", Journal of Yasar University, 10 (39), 6555-6661, 2015.

8. Genel seçim 2002.(2018 September, 24). Retrieved from https://www.haberturk.com/secim2002. 
International Conference on Research in

Humanities and Social Sciences

Serbia | Belgrade | December 15-17, 2018

9. Graber, D.A. and Smith, J.M.: "Political communication faces the 21st century", Journal of Communication, 55 (3), 479-507, 2005.

10. Internet world stats. (2018, September 12). Retrievedfromhttps://www.internetworldstats.com

11. Lilleker, D. H.: Key concepts in political communication, Sage, 2006.

12. Mosco, V. and Foster, D.: "Cyberspace and the end of politics", Journal of Communication Inquiry, 25, 218-236, 2001.

13. Norris, P.: Political communications for comparative politics, ed. Daniele Caramani, Oxford University Press, 2013.

14. Tokgöz, O.: Siyasal iletişimi anlamak, İmge, 2008.

15. Turkey elections 2018: Understanding the political parties. (2018 September, 10). Retrieved from https://www.trtworld.com/turkey/turkey-elections-2018-understanding-political-parties-18224. 